\title{
Anticonvulsant activity of nicardipine in experimentally induced seizures in wistar albino rats
}

\author{
Kayalvizhi M. K.* \\ Department of Pharmacology, Annapoorna Medical College and Hospital, Salem, Tamil Nadu, India
}

Received: 01 February 2020

Accepted: 17 February 2020

*Correspondence:

Dr. Kayalvizhi M. K.,

Email: drkayalsiva@ rediffmail.com

Copyright: $(\odot$ the author(s), publisher and licensee Medip Academy. This is an open-access article distributed under the terms of the Creative Commons Attribution Non-Commercial License, which permits unrestricted non-commercial use, distribution, and reproduction in any medium, provided the original work is properly cited.

\begin{abstract}
Background: The objective of the study was to evaluate the anticonvulsant activity of nicardipine in wistar albino rats.

Methods: Anticonvulsant activity of nicardipine in a dose $10 \mathrm{mg} / \mathrm{kg}$, and its effect with the standard drug lamotrigine $(5 \mathrm{mg} / \mathrm{kg}$ ) was studied in a maximal electroshock seizures (MES) experimental animal model.

Results: Nicardipine in dose of $10 \mathrm{mg} / \mathrm{kg}$ showed significant anticonvulsant effect $(\mathrm{p}<0.001)$ and combination with standard drug lamotrigine $(\mathrm{p}<0.001)$ also showed more significant anticonvulsant effect in MES model.

Conclusions: Nicardipine is having anticonvulsant activity and it also potentiates the anticonvulsant effect of lamotrigine in MES model.
\end{abstract}

Keywords: Nicardipine, Anticonvulsant, Maximal electroshock seizures, Lamotrigine

\section{INTRODUCTION}

Epilepsy is a chronic neurological disease, causes disability and affects about $1 \%$ of the human population. Many antiepileptic drugs (AEDs) are available in the management of seizures. Some of the first-generation AEDs used to treat epilepsy for several decades are phenobarbital, phenytoin, carbamazepine and valproic acid. According to the seizure type, spectrum of clinical activity, side effect profile and patient characteristics such as age, comorbidities and concurrent treatments, the choice of the AEDs may vary. ${ }^{1}$ AEDs have different mechanism of actions like prolonged sodium channel inactivation, calcium channel blockade, gamma-amino butyric acid (GABA) agonism, N-methyl-D-aspartate (NMDA) receptor blockade, $\alpha$-amino-3-hydroxy-5methyl-4-isoxazolepropionic acid (AMPA) receptor blockade, potassium channel blockade and activation. ${ }^{2,3}$ The pharmacokinetics of older AEDs tend to exhibit marked inter-individual variability. Routine therapeutic drug monitoring is necessary for many of the older AEDs, such as phenobarbital, carbamazepine, valproic acid and phenytoin. Because of these disadvantages of the first-generation AEDs, like narrow therapeutic index, cost and narrow spectrum of activity, many newer drugs with specific advantages were introduced among them lamotrigine is commonly used now a days. ${ }^{4}$

Because of various etiology and pathogenesis complete cure of epilepsy is still a challenge in the medical field. As it is already known that calcium is involved in the pathophysiology of seizure. Seizure activity mainly occurs due to influx of extracellular calcium which causes depolarisation of the neuronal membrane leads to opening of sodium channels and generation of repetitive action potentials. ${ }^{5,6}$ Calcium channel also mediate the release of neurotransmitter. As there is role of calcium channels in the initiation of seizure potential, there may 
be a role of calcium channel blocker (CCBs) in the treatment of epilepsy.

CCBs can be divided into dihydropyridines and non dihydropyridines (verapamil, diltiazem). dihydropyridines include amlodipine, nifedipine, nimodipine and nicardipine primarily used in the treatment of cardiac diseases like angina, arrhythmia and hypertension. ${ }^{7}$ Some studies have shown that not all drugs in this group produce adjuvant effect with known antiepileptic drugs. In this study dihydropyridine group of calcium channel blocker nicardipine was studied for its anticonvulsant property alone and its effect with a newer antiepileptic drug lamotrigine.

\section{METHODS}

\section{Experimental animals}

The study was conducted after obtaining approval from the Institutional Animal Ethics committee. 24 wistar albino rats of either sex weighing between 150 to 200 gms were randomly selected from central animal facility. All the animals were maintained in accordance with the guidelines of CPCSEA. The animals were acclimatized to the laboratory conditions ( 12 hourly dark or light, 25 degree C).

\section{Chemicals}

Nicardipine, lamotrigine (obtained from sigma chemicals) and normal saline were used.

\section{Maximal electroshock seizure model using the electroconvulsiometer}

24 hours before testing of anticonvulsants (to avoid any possible kindling effect), the animals were pre-screened for their ability to develop full tonic extension in the maximal electroshock test. Only those animals showed hind limb tonic extension response were used for maximal electroshock test.

Electrical stimulation was applied via ear electrodes with a current strength of $150 \mathrm{~mA}$ for $0.2 \mathrm{sec}^{8}{ }^{8}$ The resultant seizure passes through various phases; phase of tonic limb flexion (1.5 sec duration), phase of tonic hind limb extension (10 sec duration), finally followed by post ictal depression. Suppression of tonic hind limb extension was taken as measure of efficacy in this test.

Animals were fasted overnight but water was given ad libitum. Nicardipine and lamotrigine were procured from Sigma Aldrich. All the drugs were given by intraperitoneal injection 30 minutes before the start of the experiment. 4 groups of rats, each having 6 were taken for the study. Group I (control) rats were treated with $0.5 \mathrm{ml}$ of normal saline, group II (standard) rats were treated with lamotrigine ( $5 \mathrm{mg} / \mathrm{kg}$ body weight), group III rats received lamotrigine $(5 \mathrm{mg} / \mathrm{kg} \mathrm{BW})$ and nicardipine $(10$ $\mathrm{mg} / \mathrm{kg} \mathrm{BW})$, group IV rats were received nicardipine (10 $\mathrm{mg} / \mathrm{kg} \mathrm{BW}$ ).

\section{Statistical analysis}

The experimental data were expressed as mean \pm SEM. Statistical analysis was carried out by one way analysis of variance (ANOVA). A level for $p<0.05$ was considered to be statistically significant. IBM SPSS statistics (C) IBM Corporation 2012 software was used for statistical analysis purpose.

\section{RESULTS}

In maximal electroshock seizure (MES) model group III significantly decreased the duration of THLE (1.48 \pm 0.38 seconds) compared to their individual groups group IV $\left(2.42 \pm 0.06^{* *}\right)$ and group II $\left(0.60 \pm 0.26^{* *}\right)$. The duration of tonic hind limb extension (THLE) was significantly decreased with group IV $(2.42 \pm 0.06 * *)$ in comparison to group I (13.08 \pm 0.45 seconds) (Table 1$)$.

Group IV (nicardipine in doses $10 \mathrm{mg} / \mathrm{kg}$ ) significantly decreased the duration of flexion $(3.42 \pm 0.45)$ in comparison to group I (control- $6.5 \pm 0.20$ seconds). Group III (combination of nicardipine $10 \mathrm{mg} / \mathrm{kg}$ and lamotrigine $5 \mathrm{mg} / \mathrm{kg}$ ) significantly decreased the duration of flexion $(2.74 \pm 0.30$ seconds) in comparison to their individual groups group IV (nicardipine $10 \mathrm{mg} / \mathrm{kg} 3.42 \pm 0.45$ ) and group II (lamotrigine $5 \mathrm{mg} / \mathrm{kg} 1.48 \pm 0.23$ seconds) (Table $1)$.

Table 1: Effect of nicardipine on seizure in MES model.

\begin{tabular}{|lllll|} 
Groups & Drug and dose & $\begin{array}{l}\text { Duration of } \\
\text { flexion in sec }\end{array}$ & $\begin{array}{l}\text { Duration of } \\
\text { THLE in sec }\end{array}$ & $\begin{array}{l}\text { Duration of post ictal } \\
\text { depression in sec }\end{array}$ \\
\hline Group I & Normal saline $0.5 \mathrm{ml}$ & $6.5 \pm 0.20$ & $13.08 \pm 0.45$ & $141.14 \pm 2.27$ \\
\hline Group II & Lamotrigine $5 \mathrm{mg} / \mathrm{kg} \mathrm{bw}$ & $1.48 \pm 0.23^{* *}$ & $0.60 \pm 0.26^{* *}$ & $240.28 \pm 14.28^{* *}$ \\
\hline Group III & $\begin{array}{l}\text { Lamotrigine } 5 \mathrm{mg} / \mathrm{kg} \mathrm{bw} \text { and } \\
\text { nicardipine } 10 \mathrm{mg} / \mathrm{kg} \mathrm{bw}\end{array}$ & $2.74 \pm 0.30^{* *}$ & $1.50 \pm 0.37 * *$ & $232.57 \pm 3.90^{* *}$ \\
\hline Group IV & Nicardipine $10 \mathrm{mg} / \mathrm{kg} \mathrm{bw}$ & $3.42 \pm 0.45^{* *}$ & $2.42 \pm 0.06^{* *}$ & $206.00 \pm 4.58^{* *}$ \\
\hline
\end{tabular}

Each value is the mean \pm SEM for 6 rats, ${ }^{*} \mathrm{p}<0.05 ; * * \mathrm{p}<0.001$ compared with control. Data were analyzed by using One-way ANOVA.

Group IV (nicardipine $10 \mathrm{mg} / \mathrm{kg}$ ) significantly increased the duration of postictal depression $(206.00 \pm 4.58$ seconds) in comparison to group I (141.14 \pm 2.27 seconds). Group III, combination group significantly increased the 
duration of PIS (232.57 \pm 3.90 seconds) in comparison to their individual drugs (nicardipine $10 \mathrm{mg} / \mathrm{kg}(206.00 \pm 4.58$ and lamotrigine $5 \mathrm{mg} / \mathrm{kg}(240.28 \pm 4.28$ seconds $)$ alone (Table 1).

\section{DISCUSSION}

Even though many antiepileptic drugs available now a days, the main setback is their adverse effects and the therapeutic dose limits. Many patients remain refractory to current medical measures.

In literature there are studies on role of calcium on the generation of epileptic activity. The influx of calcium into the intracellular space which causes intrinsic burst firing is the first step in the generation of epileptic activity lead to synchronous burst firing of multiple neurons. ${ }^{9,10}$ Experimental studies showed a decrease in the extracellular concentrations of calcium in epilepsy. This is associated with the production of a paroxysmal depolarizing shift (PDS), an abnormal long-duration action potential, PDSs may also depend on synchronization of a network of neurons through synaptic mediation. It was demonstrated that calcium flux into the presynaptic terminal is an important factor for neurotransmission. ${ }^{11,12}$ De Lorenzo has postulated that calcium enters the presynaptic terminal and binds to calmodulin, a major calcium receptor protein in the neurons. The Ca-calmodulin complex regulates several aspects of synaptic activity, e.g. neurotransmitter release and neuronal function. ${ }^{13,14}$ There are some evidence that carbamazepine (CBZ), phenytoin (PHT) and benzodiazepines (BZDs) inhibit protein phosphorylation stimulated by the Ca- calmodulin complex. At a cellular level, antiepileptic drugs were found to decrease neuronal excitability by interacting with voltage dependent calcium channels, by modulating GABA metabolism, transport, and by affecting ionotropic glutamate receptors. Schumacher et al. demonstrated that PHT selectively altered low-voltage-activated calcium channels in cultured hippocampal neurons, neuroblastoma cells and rodent thalamic neurons. Epileptic depolarizations of neurons were found to be depressed by calcium channel blockers. So, there may be a role of calcium channel blockers (CCBs) in the treatment of epilepsy. CCBs are potent blockers of the voltage dependent $\mathrm{L}$ and $\mathrm{T}$ type calcium channels and there is difference in the affinity of the various drugs to block the channels. Further studies are required for anticonvulsant activity, since there are differences in pharmacological actions and therapeutic actions of CCBs. Few experimental studies have shown that among CCBs, flunarizine has got the maximum affinity for neuronal $\mathrm{L}$ and $\mathrm{T}$ type channels. Amlodipine exhibits unique features like smooth and gradual onset of action compared to other CCB. only few studies have been done on anticonvulsant activity of nicardipine. ${ }^{15}$

The present study is done to evaluate the anticonvulsant activity of nicardipine in albino rats in the experimental animal model that included MES model. Hassan et al, showed anticonvulsant effect of amlodipine when used in combination with lamotrigine, topiramate and gabapentin. The result of the study stated that CCBs can be used as potential adjuvant drugs. However, studies on different species, epilepsy models and comparison with other antiepileptic drugs need to be done to answer the question of their use in epilepsy either as monotherapy or in combination with other antiepileptic drugs.

The efficacy of nicardipine to change the parameters in MES test in the present study correlates well with the ability to prevent generalized tonic clonic seizures and it is said that this model evaluates the capacity to prevent seizure spread. In MES model, nicardipine in a dose of 10 $\mathrm{mg} / \mathrm{kg}$ and lamotrigine $5 \mathrm{mg} / \mathrm{kg}$ produced significant decrease in duration of flexion, tonic hind limb extension. and significantly increased the duration of postictal depression which showed the potentiating effect of nicardipine when used with lamotrigine.

One study stated that following systemic administration, nicardipine suppressed all phases of the audiogenic seizure, in particular significant reduction of clonic and tonic phases of audiogenic seizure. clearly, different classes of calcium antagonists acting at the calcium channel, or intracellularly, are effective as anticonvulsants, indicating that inhibition of $\mathrm{Ca} 2+$ influx or prevention of $\mathrm{Ca} 2+$ release from intracellular stores can antagonize the enhanced excitatory transmission occurring in DBA/2 mice after auditory stimulation. ${ }^{16}$ Since, lamotrigine acts both by sodium channel inactivation and calcium channel blockade nicardipine potentiates the action of lamotrigine.

\section{Funding: No funding sources}

Conflict of interest: None declared

Ethical approval: The study was approved by the Institutional Ethics Committee

\section{REFERENCES}

1. Rao SKN, Subbalakshmi NK. An experimental study of the anticonvulsant effect of amlodipine in mice. Singapore Med J. 2010;51(5):428.

2. Nei M, Ho RT, Sperling MR. EKG abnormalities during partial seizures in refractory epilepsy. Epilepsia. 2000;41:542-8.

3. Lowenstein DH. Seizure and epilepsy. In: Braunwald E, Fauci AS, Hauser SL, eds. Harrison's Principles of Internal Medicine. 15th ed. New York: McGraw-Hill; 2001: 2354-2369.

4. Tripathi KD. Essentials of Medical Pharmacology. 7th ed. New Delhi: Jaypee; 2013: 546.

5. Roopa B, Janardhan M, Rao VY. Evaluation of anticonvulsant activity of amlodipine in albino rats. Int J Basic Clin Pharmacol. 2017;6(3):664-8.

6. Kalabharathi HL, Sushma V, Pushpa VH, Satish AM. Anticonvulsant activity of calcium channel blockers on experimentally induced seizures in animal models. Int J Pharm Pharm Sci. 2014;6(1):541-6. 
7. Sahadevan P, Rema MN. A comparative experimental study of the anticonvulsant effect of three calcium channel blockers in albino mice. Indian J Pharmacol. 2002;34:52-5.

8. Hassan MAG, Masoud AD. Effect of amlodipine on the antiepileptic action of lamotrigine, gabapentin and topiramate on maximal electroshock induced seizures in mice. Natl J Physiol Pharm Pharmacol. 2014;4(3):201.

9. $\mathrm{G}^{1}$ sior $\mathrm{M}$, Kamiñski $\mathrm{R}$, Brudniak $\mathrm{T}$, Kleinrok Z, Czuczwar SJ. Influence of nicardipine, nimodipine and flunarizine on the anticonvulsant efficacy of antiepileptics against pentylenetetrazole in mice. J Neural Transm. 1996;103:819-31.

10. $\mathrm{G}^{\mathbf{1}}$ sior $\mathrm{M}$, Kleinrok $\mathrm{Z}$, Czuczwar SJ. Influence of BAY k-8644, a calcium channel agonist, on the anticonvulsant activity of conventional antiepileptics against electroconvulsions in mice. Neuropharmacology. 1995;34:433-8.

11. Beck H. Plasticity of antiepileptic drug targets. Epilepsia. 2007;48(1):14-8.

12. Schumacher TB, Beck H, Steinhaiser C, Schramm J, Elger CE. Effects of phenytoin, carbamazepine and gabapentin on calcium channels in hippocampal granule cells from patients with temporal lobe epilepsy. Epilepsia, 1998;39:355-63.

13. Pathan SA, Jain GK, Akhter S, Vohora D, Ahmad FJ, Khar RK. Insights into the novel three 'D's of epilepsy treatment: drugs, delivery systems and devices. Drug Discov Today. 2010;15(17-18):717-32.

14. $\mathrm{Ku}^{3} \mathrm{ak}$ W, Sobaniec W, Wojtal K, Stanis ${ }^{3} \mathrm{aw}$ J. Czuczwar calcium modulation in epilepsy. Pol $\mathbf{J}$ Pharmacol. 2004;56:29-41.

15. wi1'der M, Borowicz KK, Porêbiak J, Kleinrok Z, Czuczwar SJ. Influence of agents affecting voltage dependent calcium channels and dantrolene on the anticonvulsant action of the AMPA/kainate receptor antagonist LY 300164 in mice. Eur Neuropsychopharmacol. 2002;12:311-9.

16. Stephen CC. Voltage-gated ion channelopathies of the nervous system. Clin Neurosci Res. 2001;1:10417.

Cite this article as: Kayalvizhi MK. Anticonvulsant activity of nicardipine in experimentally induced seizures in wistar albino rats. Int J Basic Clin Pharmacol 2020;9:413-6. 